Vol. 2 | No. 3 | 2021 | Hal. 210-215

\title{
SOSIALISASI PEMBERDAYAAN MASYARAKAT MENGENAI STRATEGI BRANDING DAN INOVASI PRODUK KRIPIK GADUNG GUNA MENINGKATKAN EKONOMI KREATIF DI MASA PANDEMI
}

\author{
M. Ridwan Basalamah*, Adinda Bella P, Annisa Mutmainah, Alisha Ramadhania, \\ Laidia Himmatul Ulya, Alviana Mariska, Dwi Mayangsari \\ Fakultas Ekonomi dan Bisnis, Universitas Islam Malang \\ *korespondensi email: ridwanbasalamah@unisma.ac.id
}

\begin{abstract}
ABSTRAK
Perkembangan bisnis yang semakin pesat tentunya menciptakan persaingan yang sangat ketat, tanpa terkecuali pada UMKM. Pada akhirnya persaingan yang ketat inilah menuntut para pelaku UMKM untuk bisa menciptakan sebuah ekonomi kreatif agar dapat bisa bertahan dan mengembangkan usahanya, salah satunya menciptakan inovasi dan branding produk. Terlebih dalam situasi pandemi covid-19 apabila suatu UMKM tidak menciptakan ekonomi kreatif maka akan rentan mengalami penurunan dalam berbagai aspek salah satunya brand atau citra merk di mata masyarakat. menciptakan inovasi tentunya berani berpikir secara positif, berani mengambil resiko, serta mampu dalam menghadapi segala perubahan. Untuk itu diperlukan sosialisasi, edukasi, dan pelatihan mengenai strategi branding dan inovasi produk bagi pelaku usaha kripik gadung di Dusun Glagah Ombo Desa Sumbersuko yang terletak di Kecamatan Wagir Kabupaten Malang ini. Kegiatan ini bertujuan memberikan pengetahuan dan pemahaman strategi branding dan Inovasi produk dengan harapan UMKM didusun Glagah Ombo ini mampu bersaing dalam bisnis global.
\end{abstract}

Kata Kunci: kripik gadung; inovasi; branding; ekonomi kreatif

\section{PENDAHULUAN}

Usaha Mikro Kecil dan Menengah (UMKM) merujuk pada usaha ekonomi produktif yang berdiri sendiri, dilakukan oleh perseorangan atau badan usaha yang bukan merupakan anak perusahaan dengan kriteria aset sebesar Rp50 juta dan omzet di bawah Rp200 juta. Pengertian UMKM dapat dilihat dari beberapa aspek. Bagi pelaku usaha, UMKM adalah bisnis atau usaha yang dijalankan oleh perseorangan, rumah tangga, maupun badan usaha kecil (Rizal et al., 2019). Dalam perekonomian Indonesia, sektor usaha kecil dan menengah memegang peranan penting, terutama bila dikaitkan dengan jumlah tenaga kerja yang mampu diserap oleh usaha kecil dan menengah tersebut. Selain memiliki arti strategis bagi pembangunan, UMKM juga berfungsi sebagai sarana untuk memeratakan hasil-hasil pembangunan yang telah dicapai (Hafni \& Rozali, 2017; Tampubolon \& Ningsih, 2019).

Salah satu faktor yang harus terus diperbaiki untuk bisa mendorong UMKM di level daerah bersaing di kancah internasional adalah branding yang dapat dilihat sebagai salah satu titik elemen kritis dalam kesuksesan sebuah organisasi (Anggraeni et al., 2013). Merek atau brand akan mempengaruhi perilaku konsumen dalam membeli. Merek memberikan nilai tambah (added value) terhadap produk yang dihasilkan. 
Branding merupakan upaya memperkuat merek produk ataupun jasa. Sebab fungsi dasar dari sebuah merek adalah sebagai pembeda antara yang satu dengan yang lainnya. Ada beberapa unsur-unsur yang mempengaruhi kekuatan sebuah merek, dari apa yang terlihat (tangible) dan dari apa yang terdengar dan apa yang dirasakan (intangible) (Wulandari, 2013; Yunaida, 2018). Unsur-unsur tersebut merupakan prasyarat utama dalam membangun kekuatan sebuah merek didalam konteks kompetisi pasar. Kedua unsur tersebut yakni; Pertama, tangible seperti produk, packaging atau kemasan, identitas visual. Kedua, intangible seperti kualitas produk dan jasa.

Salah satu kunci sukses dalam upaya meningkatkan branding sebuah produk adalah mempromosikan lewat sosial media. Dalam konteks ini branding merupakan upaya memperkuat merek produk dan jasa baik dalam skala besar maupun kecil (Moriansyah, 2015; Sari et al., 2021). Jadi tidak heran, baik buruknya upaya kita untuk memperkuat merek produk sangat tergantung dari cara mengelola media sosial. Hal ini disebabkan semakin hari peran media sosial semakin menjadi rujukan utama dalam membangun branding produk serta menentukan keberhasilan kita dalam membangun branding.

Selain branding terdapat juga sebuah Inovasi produk yang dapat menunjang dalam pemasaran dan penjualan produk. Produk yang dihasilkan UMKM sering kali masih kalah bersaing dengan produk yang dihasilkan oleh usaha besar, baik dari segi inovasi produk, kualitas produk, maupun distribusi produk. Persaingan antara sesama pelaku UMKM dan persaingan dengan usaha besar seringkali menjadi hambatan bagi UMKM untuk mengembangkan dan memperluas usahanya. Komponen produk (output) yang dihasilkan UMKM pun menjadi unsur yang penting untuk diperhatikan oleh pelaku UMKM. Mereka yang mampu menyajikan produk yang lebih unggul melalui inovasi memiliki peluang yang lebih besar untuk menarik minat konsumen. Inovasi tidak bisa dilepaskan dari kehidupan berbisnis karena inovasi merupakan roh atau jiwa dalam sebuah perusahaan untuk berkembang, inovasi dapat berkembang dimana saja dan dilakukan oleh siapa saja, inovasi tidak hanya dilakukan oleh perusahaan besar, melainkan perusahaan kecil pun perlu untuk melakukan inovasi demi keberlangsungan usahanya (Dhewanto et al., 2014). Menurut Peter Ducker (1954) dalam Dhewanto et al. (2014) sebuah perusahaan yang kompetitif memiliki dua tujuan penting, yaitu menciptakan nilai pelanggan (customer value) dan inovasi.

Di Masa Pandemi Covid-19 UMKM harus bisa menciptakan sebuah ekonomi kreatif agar dapat bisa bertahan dan mengembangkan usahanya, seperti menciptakan branding dan inovasi produk di samping peningkatan penjualan produk serta menciptakan penetrasi pasar yang lebih baik. Keberadaan pengusaha ekonomi kreatif nyatanya masih belum stabil di masa Pandemi Covid-19.

Kurangnya pemahaman branding dan Inovasi tentang olahan kripik gadung membuat kurangnya meluas pangsa pasar untuk mengenali Branding sebuah produk yang dimana juga dirasakan oleh seluruh pelaku UMKM kripik gadung yang ada di Dusun Glagah Ombo yang terletak di Kecamatan Wagir Kabupaten Malang. UMKM olahan kripik gadung merupakan salah satu UMKM yang banyak dijadikan mata pencaharian utama oleh warga Glagah Ombo. Hal ini karena mayoritas warganya bekerja sebagai petani dan produsen umbi gadung. umbi gadung yang dihasilkan oleh warga memiliki potensi yang cukup baik apabila dikelola dengan baik dan tepat. Namun karena kurangnya pengetahuan dan pemahaman warga mengenai branding dan Inovasi olahan kripik gadung membuat penjualan tidak meningkat karena kurang meluasnya pangsa pasar. Selain itu, pelaku UMKM olahan kripik gadung tersebut juga masih memproduksi kripik gadung tanpa adanya branding dan inovasi produk. 
Dengan melimpahnya kekayaan umbi gadung di desa sumbersuko terutama di dusun glagah ombo, membuat beberapa warga tersebut membuat sebuah usaha olahan dari umbi gadung yaitu keripik gadung. Dari Permasalahan tersebut tidak semua orang memiliki pemahaman yang mendalam tentang kegiatan ekonomi kreatif. Ketergantungan pada hasil pertanian yang dikelola secara lokal terkadang membuat masyarakat kurang berinovasi. tahapan strategi pemasaran serta inovasi varian rasa baru sehingga diharapkan mampu bersaing dalam bisnis global melalui digital marketing.

Dari permasalahan tersebut maka perlu adanya sosialisasi, edukasi, dan pelatihan mengenai strategi branding dan Inovasi Produk guna meningkatkan Ekonomi Kreatif. Hal ini menjadi salah satu peluang sekaligus tantangan bagi pelaku UMKM olahan Kripik Gadung agar memiliki daya saing dan Ide kreatif yang sangat dibutuhkan untuk memenangkan persaingan dalam industri.

Tujuan dilakukannya adanya sosialisasi, edukasi, dan pelatihan mengenai strategi branding dan Inovasi Produk pada pelaku UMKM olahan Kripik Gadung yaitu untuk meningkatkan ekonomi kreatif dan pengetahuan masyarakat tentang bagaimana membangun sebuah branding dan inovasi produk terhadap olahan kripik gadung.

\section{METODE}

Target utama kami melakukan sosialisasi ini keberapa pelaku UMKM Kripik Gadung yang ada di desa Sumbersuko dengan menyusun program kerja umum untuk meningkatkan strategi branding dan Inovasi produk guna meningkatkan ekonomi kreatif dimasa pandemi covid-19 saat ini. Sebelum melakukan program kegiatan, kami melakukan survey terlebih dahulu dan telah diijinkan oleh kepala desa setempat. Tahap selanjutnya kami mulai melaksanakan proses branding dan Inovasi Produk yang sudah dijadwalkan sesuai rencana program kerja dengan tetap mematuhi protokol kesehatan, adapun beberapa pokok permasalahan yang dibahas dalam sosialisasi yang kita lakukan yaitu (1) Sosialisasi dan Edukasi tentang pentingnya branding pada produk kripik Gadung; (2) Inovasi pada Olahan kripik Gadung; (3) Pelatihan pemasaran produk melalui Digital Marketing.

Sosialisasi yang kami lakukan difokuskan pada pelaku UMKM Kripik Gadung yang berada di wilayah Desa Sumbersuko Dusun Glagah Ombo RT/RW 07/24, Selama 1 Minggu Pada Tanggal 30 Agustus - 3 September 2021, mengacu pada peraturan pemerintah agar tidak membuat kerumunan pada masa pandemi sehingga kegiatan dilakukan dari rumah ke rumah dengan harapan mencegah penularan Covid-19 dan dapat meningkatkan perekonomian warga desa Sumbersuko khususnya pelaku UKM Kripik Gadung.

\section{HASIL DAN PEMBAHASAN}

Selama beberapa hari melaksanakan program kerja, kami memperoleh hasil dari pengamatan di lapangan bahwa hampir semua pelaku UMKM Kripik Gadung belum melakukan branding dan inovasi pada produk mereka. Hal ini terjadi karena kurangnya pengetahuan masyarakat desa Sumbersuko khususnya dusun Glagah Ombo tentang cara berbisnis yang tepat. Selain itu para pelaku UMKM juga kesulitan dalam melakukan penjualan produk Kripik Gadung kecuali pada pengepul atau juragan. Oleh sebab itu, penjualan dilakukan dengan monopoli harga kripik gadung yang telah di tetapkan oleh pengepul, sehingga untuk menaikkan penghasilan sangat sulit.

Pada tahap pertama melakukan sosialisasi pentingnya branding dan inovasi kripik gadung untuk meningkatkan ekonomi kreatif pada masa pandemi Covid-19 saat ini, kami memberikan penjelasan yang rinci dan jelas agar mudah dipahami warga sekitar. Penggunaan bahasa yang santai dan bahasa sehari-hari pada saat sosialisasi menjadikan banyak warga mudah mengerti dan memahami apa itu bisnis dan seberapa penting 
melakukan bisnis pada saat ini. Antusiasme pengusaha kripik gadung sangat membantu kesuksesan kegiatan pada tahap pertama ini.

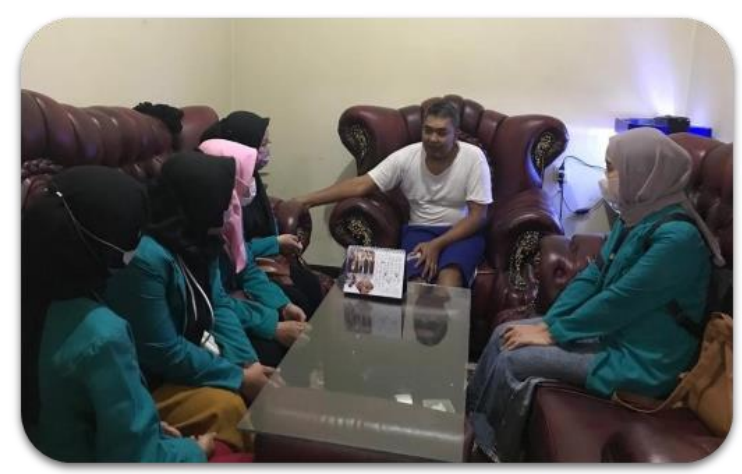

Gambar 1. Sosialisasi dan edukasi tentang branding dan Inovasi Produk Kepada Produsen Kripik Gadung

Kemudian tahap kedua, kami melakukan pendampingan inovasi dan branding produk dengan membuat varian rasa yang baru dan mendesain kemasan yang menarik. Agar terlihat menarik Desain kemasan produk menggunakan tips berikut: (1) Menggunakan Desain yang Sederhana; (2) Menggunakan Warna Cerah dan Berbeda; (3) Memanfaatkan Gambar yang Menarik; (4) Menambahkan Informasi Penting Dengan Font Menarik; (5) Menambahkan Tagline yang Menarik; (6) Menggunakan Kemasan dengan Bahan Berbeda dan Terjangkau.

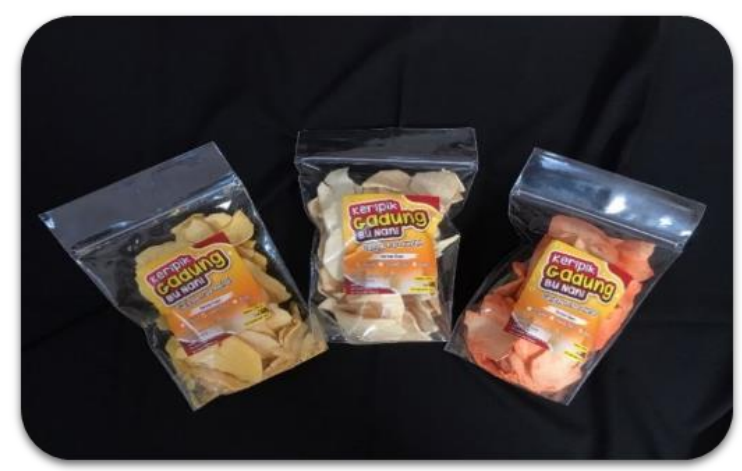

Gambar 2. Melakukan Inovasi dan Labeling terhadap Kripik Gadung

Tahap ketiga yaitu sosialisasi mengenai pemasaran online sehingga pelaku UMKM kripik gadung dapat menggunakan digital marketing untuk melakukan pemasarannya secara langsung. Pengetahuan tentang digital marketing dirasa sangat penting mengingat perkembangan teknologi yang kian hari berkembang pesat. Dengan mengenal digital marketing diharapkan pelaku UMKM kripik gadung dapat mengembangkan usahanya melalui media digital agar lebih dikenal masyarakat luas. Dalam sosialisasi juga diberikan tips menjalankan sosial media marketing yaitu diantaranya (1) Menarik Pelanggan Potensial; (2) Membangun Relasi di Media Sosial; (3) Membuat Konten yang menonjolkan nilai; (4) Menggunakan Gambar yang Baik dan Menarik; (5) Berpartisipasi Dalam Kelompok dan Komunitas Online.

Strategi pemasaran online atau digital marketing pada zaman sekarang yang mengikuti perkembangan zaman guna memperlancar arus perdagangan di desa Sarongan. Selain itu, tujuan pengenalan inovasi produk untuk menambah nilai jual dari gula merah yang akan menstabilkan penjualan produk tersebut. Pada akhirnya diharapkan sosialiasi ini akan meningkatkan pendapatan UKM khususnya pada era pandemi ini. 
Setelah itu membantu melakukan perhitungan BEP (Break Even Point) terhadap inovasi dan branding produk yang dilakukan serta mensosialisasikannya kepada pelaku usaha. perhitungan BEP dilakukan dengan tujuan untuk Menentukan jumlah minimum penjualan yang harus dipertahankan agar tidak mengalami kerugian. Serta Menentukan jumlah penjualan yang harus dicapai untuk mendapatkan keuntungan agar jumlah penjualan tidak merugi.

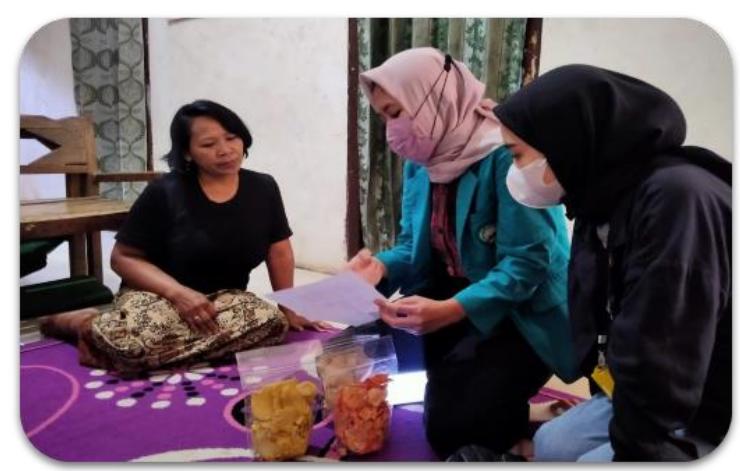

Gambar 3. Pelatihan Tentang Digital Marketing

\section{KESIMPULAN}

Masih banyak masyarakat Desa Sumbersuko Dusun Glagah Ombo, Kecamatan Wagir, Kabupaten Malang yang belum memahami bagaimana cara berbisnis dengan tepat pada saat ini. Sehingga penghasilan yang diperoleh sulit untuk mengalami peningkatan ditambah adanya pandemi Covid-19 yang berdampak pada merosotnya perekonomian di Indonesia. Untuk mengatasi hal tersebut, kami melakukan edukasi, pelatihan dan sosialisasi mengenai usaha milik $\mathrm{Bu}$ Nani selaku produsen kripik gadung mulai dari pembuatan inovasi dan branding produk hingga pengenalan digital marketing. Setelah kegiatan ini, pelaku usaha menjadi lebih sadar akan pentingnya inovasi produk dan pemasaran melalui digital marketing. Faktor waktu, biaya dan keterbatasan ruang gerak di masa pandemi Covid-19 menjadi beberapa kendala yang kami hadapi untuk memaksimalkan program kerja kami, sehingga kami berharap untuk pengabdian di masa mendatang dapat memonitor hasil dari sosialisasi yang telah dilakukan serta merambah lebih banyak UKM.

\section{UCAPAN TERIMA KASIH}

Ucapan terima kasih disampaikan kepada Kepala Desa Sumbersuko beserta perangkat Desa Sumbersuko yang telah menerima dan membantu mahasiswa KSM UNISMA dalam menjalankan program kerja. Ucapan terima kasih kepada Seluruh Anggota Keluarga Ibu Nani Produsen Kripik Gadung, serta terima kasih kepada masyarakat Desa Sumbersuko yang telah dengan aktif mengikuti pelatihan dan kegiatan selama KSM berlangsung.

\section{DAFTAR RUJUKAN}

Anggraeni, F. D., Hardjanto, I., \& Hayat, A. (2013). Pengembangan Usaha Mikro, Kecil, Dan Menengah (UMKM) Melalui Fasilitasi Pihak Eksternal Dan Potensi Internal (Studi Kasus pada Kelompok Tani "Emping Jagung" di Kelurahan Pandanwangi Kecamatan Blimbing, Kota Malang). Jurnal Administrasi Publik, 1(6), 1286-1295. http://administrasipublik.studentjournal.ub.ac.id/index.php/jap/article/view/195

Dhewanto, W., Mulyaningsih, H. D., Permatasari, A., Anggadwita, G., \& Ameka, I. (2014). Manajemen Inovasi, Peluang Sukses Menghadapi Perubahan (1st ed.). Andi.

Hafni, R., \& Rozali, A. (2017). Analisis Usaha Mikro, Kecil, dan Menengah (UMKM) terhadap Penyerapan Tenaga Kerja di Indonesia. Ekonomikawan Jurnal Ilmu Ekonomi Dan Studi 
Pembangunan,

15(2),

77-96.

https://doi.org/10.30596\%2Fekonomikawan.v15i2.1034

Moriansyah, L. (2015). PEMASARAN MELALUI MEDIA SOSIAL : ANTECEDENTS DAN CONSEQUENCES SOCIAL MEDIA MARKETING : ANTECEDENTS AND CONSEQUENC-. Jurnal Penelitian Kominikasi Dan Opini Publik, 19(3), 187-196. https://doi.org/10.33299/jpkop.19.3.346

Rizal, M., Mustapita, A. F., \& Kartika Sari, A. F. (2019). Pelatihan Untuk Pengajuan Pembiayaan Mudharabah Perbankan Syariah Sebagai Peningkatan Kinerja UMKM. Jurnal Inovasi Hasil Pengabdian Masyarakat (JIPEMAS), 3(1), 15-22. https://doi.org/10.33474/jipemas.v3i1.2569

Sari, W. E., Yulianto, Junirianto, E., Franz, A., Karim, S., \& Khamidah, I. M. (2021). Video branding untuk promosi usaha mikro kecil menengah (UMKM). Jurnal Inovasi Hasil $\begin{array}{lll}\text { Pengabdian Masyarakat } & \text { (JIPEMAS), }\end{array}$ https://doi.org/10.33474/jipemas.v4i1.7174

Tampubolon, R. P., \& Ningsih, D. (2019). Analisis Usaha Kecil Menengah (UKM) terhadap Penyerapan Tenaga Kerja di Batam. Jurnal Mirai Managemnt, 4(2), 263-272. https://doi.org/10.37531/mirai.v4i2.516

Wulandari, T. (2013). Analisis Place Branding untuk Meningkatkan Citra Kabupaten Purwakarta serta Implikasinya terhadap Keputusan Mengunjungi Destinasi Pariwisata (Survei terhadap Wisatawan Nusantara yang Berkunjung ke Kabupaten Purwakarta). Jurnal Ilmu Manajemen \& Bisnis, 4(1), 1-12.

Yunaida, E. (2018). Pengaruh Brand Image (Citra Merek) terhadap Loyalitas Konsumen Produk Oli Pelumas Evalube di Kota Langsa. Jurnal Manajemen Dan Keuangan, 6(2), 798-807. https://doi.org/10.33059/jmk.v6i2.685 